\title{
A three-step purification method of large quantities of human recombinant $\alpha$ endothelial cellular growth factor for clinical use
}

\author{
ALEXANDER SAUTER ${ }^{1}$, KATHERINE L. LAMBERT ${ }^{4}$, ANN-KATRIN RUPF ${ }^{2}$, \\ BERND-ULRICH VON SPECHT ${ }^{3}$, KARL HÖRMANN ${ }^{1}$ and RAMIN NAIM ${ }^{1}$
}

\author{
Departments of ${ }^{1}$ Otorhinolaryngology, Head and Neck Surgery, ${ }^{2}$ Gastroenterology, University Hospital Mannheim, \\ D-68135 Mannheim, ${ }^{3}$ Department of Surgery, University of Freiburg, Hugstetter Street 55, D-79106 Freiburg, \\ Germany; ${ }^{4}$ Warwick Medical School, University of Warwick, Coventry CV4 7AL, UK
}

Received June 20, 2006; Accepted August 18, 2006

\begin{abstract}
The endothelial cellular growth factor $\alpha$-ECGF is a candidate drug for the induction of therapeutic neoangiogenesis. Its use in extensive experimental and clinical trials is hampered by the fact that currently published purification procedures allow only small yields, and the absence of pyrogenic impurities is not demonstrated. The rh $\alpha$-ECGF was expressed in E. coli. Isolation of rh $\alpha$-ECGF from $E$. coli lysates to apparent homogenicity was achieved by a three step purification procedure involving ionic exchange, heparin-sepharose and polymyxin B chromatography. By this method, $200 \mathrm{mg}$ of $\mathrm{rh} \alpha$-ECGF was purified from $15 \mathrm{~g}$ wet weight E. coli bacteria. The isolated protein of $18 \mathrm{kDa}$ appeared as a single band after SDS gel electrophoresis and subsequent silver-staining. The biological activity was expressed in the chorion-allantois-membrane assay and in the ${ }^{3} \mathrm{H}$-thymidine proliferation in baby hamster kidney cells. Drug trials with rabbits revealed no increase in body temperature after intravenous injections with $1 \mathrm{mg}$ rh-ECGF.
\end{abstract}

\section{Introduction}

Compromised microvascular circulation is an important component of several cardiovascular diseases including syndromes of acute coronary ischemia (1), hypertensive heart disease with left ventricular hypertrophy (2), chronic congestive cardiac failure (3), and diabetic peripheral vascular insufficiency (4).

In ischemic regions small arterioles and capillaries begin to grow. Polypeptide growth factors are thought to play an important role in the collateralization processes in response to ischemia. The heparin-binding growth factor family consists

Correspondence to: Dr Alexander Sauter, Univ.-HNO-Klinik, Universitätsklinikum Mannheim, Theodor-Kutzer-Ufer, D-68135 Mannheim, Germany

E-mail: alexander.sauter@hno.ma.uni-heidelberg.de

Key words: $\alpha$-ECGF, heparin-sepharose affinity chromatography, angiogenesis of 10 identified mitogens (5-8) and 4 homologs with unknown functions (9). Of these growth factors, acidic fibroblast growth factor (FGF-1), basic fibroblast growth factor (FGF-2), and vascular endothelial growth factor (VEGF) constitute the most widely studied group. The heparin-binding growth factors $\alpha$-ECGF and $\beta$-ECGF were first separated from bovine brain tissue by high-pressure liquid chromatography (10). $\alpha$-ECGF and FGF- 1 are processed out of $\alpha$-ECGF by posttranslational processing (10). The strong relationship between these three factors is shown by the cross-reaction of FGF-1 with ECGF-antibodies (10). $\alpha$-ECGF, $\beta$-ECGF, FGF-1 and FGF-2 are potentiated by the glycosaminoglycan heparin. $\alpha$-ECGF and FGF-1 are polypeptides of a similar molecular weight, $17 \mathrm{kDa}$ and $20 \mathrm{kDa}$ respectively. The heparin-binding growth factors appear to be cellular peptides with a mitogenic potency to mesoderm- and neuroectoderm-derived cells (11). FGF-1 and FGF-2 can induce the growth of endothelial, smooth muscle cells and fibroblasts and show a chemotactic effect on these vascular cells (12-14). Endothelial cells possess a high-affinity for these mitogenic peptides through specific receptors for FGF-2 (FGFR) on their vascular surface (15). Polysaccharide-heparansulphates appear to initiate the following signal transduction by binding FGF/FGFR and ligand-induced dimerisation of the receptor (16). The connection between heparansulphate and the extracellular FGFR-kinase induces the transphosphorylation of FGFR, which is responsible for the specificity and ligation of FGF (17).

Studies concerning the induction of new vessel formation by application of FGF-1, FGF-2 and VEGF in the ischemic heart have been promising. Intracoronary FGF-2 injections in ischemic dog myocardium reduced the size of the infarct and increased the number of capillaries (18). Lopez and colleagues achieved a functional improvement of left-ventricular parameters in ischemic porcine myocardium by FGF-1 (19). Under coronary angiography, Schumacher and associates, showed a significant growth of new vessels by FGF in the rat heart (20). In clinical studies the intramyocardial injection of FGF-1 induced the growth of new capillary networks in patients suffering from coronary heart disease (21). The application of FGF-2 reduced the size of the ischemic area and the incidence and/or severity of angina pectoris attacks (22). 
The purification of $\alpha$-ECGF from bovine brain was first described by Gospodarowicz (23). High-pressure liquid chromatography (HPLC) played the major role in the described method. In order to obtain greater amounts of ECGF for structural studies the HPLC was supplemented by heparin-sepharose affinity chromatography (10). The existing procedures were sufficient to purify relatively small quantities of mitogens (24-26). Before initiating the heparin-sepharose affinity chromatography, ECGF was pre-purified by acidtreatment, gel exclusion chromatography and ammonium sulfate precipitation (27). Previous methods of purification of ECGF by the aforementioned authors produced a singlechain polypeptide which possessed an anionic isoelectric point and a molecular weight of $20 \mathrm{kDa}(24,25,28)$. The required quantities of ECGF for clinical and experimental studies were purified by combining HPLC and heparinsepharose chromatography and other starting preparations $(10,21)$. We now describe a fast purification method using ionic exchange, heparin-sepharose affinity and polymyxin $\mathrm{B}$ chromatography. In order to produce sufficient amounts of angiogenic growth factors for further clinical and experimental studies, the described method attempts to replace HPLC by ionic exchange and heparin-sepharose affinity chromatography. Extensive studies in this area require larger quantities of biologically active angiogenic mitogens that can be produced quickly and to a high level of purity. Removing HPLC from the suggested methodology also eliminates the possibility of in vivo angiogenesis, which is thought to be caused by the TFA buffer used in HPLC (29).

\section{Materials and methods}

Plasmid and bacteria. The plasmid for the expression of human $\alpha$-ECGF in E. coli was obtained from Tom Maciag (Laboratory of Molecular Biology, American Red Cross, Rockville, MD). The $\alpha$-ECGF was integrated in a pET-3cvector from Stratagene Cloning Systems, La Jolla, USA.

The plasmid was transformed into Epicurian Coli BL 21(DE3)pLYSS-E . coli bacteria by electroporation (30). Transformed bacteria were grown on agar plates overnight and used the same day.

Induction of recombinant protein synthesis and preparation of induced cell extracts. One individual colony was expanded in each of 10 tubes in $50 \mathrm{ml} \mathrm{LB}$ medium $(10 \mathrm{~g} / \mathrm{l} \mathrm{NaCl}, 10 \mathrm{~g} / \mathrm{l}$ peptone, $5 \mathrm{~g} / 1$ yeast, $1 \%$ glucose, $100 \mu \mathrm{g} / \mathrm{ml}$ ampicillin, $\mathrm{pH} 7.5$ ) for $6 \mathrm{~h}$ at $37^{\circ} \mathrm{C}$. From each tube a $5-\mathrm{ml}$ sample was taken and analyzed for ECGF expression. The samples were grown to an optical density of $0.4\left(\mathrm{~A}_{547 \mathrm{~nm}}\right), 5 \mathrm{ml} 1 \mathrm{M}$ IPTG was added and the samples were shaken at $37^{\circ} \mathrm{C}$ for $1.5 \mathrm{~h}$. A $1-\mathrm{ml}$ probe was taken from each tube, and was analyzed after centrifugation. It was then re-suspended in $100 \mu 1$ lysis buffer by SDS electrophoresis for $\alpha$-ECGF expression.

Two tubes with high ECGF expression were pooled and distributed into 20 1-1 flasks containing $250 \mathrm{ml} \mathrm{LB}$ medium. The cells were expanded to an optical density of $0.4\left(\mathrm{~A}_{547 \mathrm{~nm}}\right)$ at $37^{\circ} \mathrm{C}$ and $140 \mathrm{rpm}$. ECGF was induced by adding $200 \mathrm{ml}$ $1 \mathrm{M}$ IPTG (1 mM final concentration). After 3-h of incubation, the cultures were pooled and centrifuged (6000 x g, $10 \mathrm{~min})$. The cell pellet $(15 \mathrm{~g})$ was suspended in $93 \mathrm{ml}$ of disruption buffer (TE buffer, 1 mM EDTA, 13 mM Tris-HCl, pH 8.0) plus $36 \mathrm{~g} / 1$ glucose, $10 \mathrm{mg} / 1$ lysozyme, $1 \mathrm{mM}$ PMSA and shaken for $30 \mathrm{~min}$ at $4^{\circ} \mathrm{C}$. The cells were disrupted by a single passage through a french press at $15000 \mathrm{kp} / \mathrm{cm}^{2}$.

Purification of recombinant $\alpha$ endothelial cellular growth factor from E. coli. After centrifugation at $45000 \mathrm{x} \mathrm{g}$ for $20 \mathrm{~min}$, the supernatant $(35 \mathrm{ml})$ was filtered through a $0.22-\mu \mathrm{m}$ filter. The filtration was first followed by an ammonium sulfate precipitation (40\% final concentration) (27). After centrifugation at $20000 \mathrm{x}$ g for $20 \mathrm{~min}$ the supernatant was saturated with ammonium sulfate to $85 \%$ and centrifuged at $20000 \mathrm{x} \mathrm{g}$ for $20 \mathrm{~min}$. The pellet was dissolved in $30 \mathrm{ml}$ of distilled water. The solution was desalted over a sephadex G 25 column $(2.7 \times 30 \mathrm{~cm})$ equilibrated with $50 \mathrm{mM}$ phosphate buffer, $0.15 \mathrm{M} \mathrm{NaCl}$, pH 7.0. A cation exchanger (CM sepharose, C 50) column $(2.6 \times 10 \mathrm{~cm})$ was equilibrated with $50 \mathrm{mM}$ phosphate buffer, $0.15 \mathrm{M} \mathrm{NaCl}, \mathrm{pH} 7.0$ at a flow rate of $3.5 \mathrm{ml} / \mathrm{min}$. The desalted solution from the sephadex $\mathrm{G} 25$ column was pumped on the column at a flow rate of $3.5 \mathrm{ml} /$ min and washed with $200 \mathrm{ml}$ equilibration buffer. Elution was performed on a linear gradient $(3.5 \mathrm{ml} / \mathrm{min}, 30 \mathrm{~min})$ mixed from $50 \mathrm{mM}$ phosphate, $0.15 \mathrm{M} \mathrm{NaCl}, \mathrm{pH} 7.0$ and $50 \mathrm{mM}$ phosphate, $0.5 \mathrm{M} \mathrm{NaCl}, \mathrm{pH}$ 7.0. The peak fraction $(90 \mathrm{ml}$ ) was collected and analyzed for $\alpha$-ECGF content by ELISA.

The peak from cation exchanger chromatography was desalted by using a sephadex G 25 column. The elution fraction containing the ECGF was passed over a G 25 (HiPrep, $2.6 \times 10 \mathrm{~cm}$ ) column under the same conditions as described above.

The heparin-sepharose affinity chromatography column $(2.6 \times 20 \mathrm{~cm})$ was packed approximately half with heparinsepharose (Pharmacia, CL-6B) and equilibrated with $10 \mathrm{mM}$ Tris- $\mathrm{HCl}, \mathrm{pH}$ 7.0. The elution fraction from the $\mathrm{G} 25$ column was pumped on the column with a flow rate of $3 \mathrm{ml} / \mathrm{min}$ and washed with $10 \mathrm{mM}$ Tris- $\mathrm{HCl}, 0.15 \mathrm{M} \mathrm{NaCl}, \mathrm{pH} 7.0$ buffer until the adsorption at $\mathrm{A}_{280 \mathrm{~nm}}$ reached baseline level. ECGF was eluted with $10 \mathrm{mM}$ Tris- $\mathrm{HCl}$, pH 7.0 buffer containing $2 \mathrm{M}$ $\mathrm{NaCl}$ at a flow rate of $3 \mathrm{ml} / \mathrm{min}$. The elution peak $(200 \mathrm{ml})$ was collected and sterilized by passing through a $0.22-\mu \mathrm{m}$ filter.

Removal of endotoxin impurities. An endotoxin-free column (BioRad, 0.5x10 cm) was packed with $1 \mathrm{ml}$ polymyxine B suspended in pyrogen-free water (aqua pro injectable). The sterile filtered elution fraction from the heparin-sepharose column was pumped over the column with a flow rate of $1 \mathrm{ml} /$ min and collected in sterile pyrogen-free tubes.

SDS-polyacrylamide gel electrophoresis and Western blotting. The polypeptides were separated in sodium dodecyl-sulfate polyacrylamide gels by a previously decribed method (31). The proteins were electroblotted onto a nitrocellulose membrane at $0.8 \mathrm{~mA} \mathrm{~cm}^{-2}$ in accordance to standard procedures. The detection of the proteins was performed by utilizing a monoclonal anti-aFGF-IgG antibody (Sigma, mouse, anti-humanFGF) at a dilution of 1:5000 and the anti-mouse-anti-IgG antibody (Dako, goat) at a dilution of 1:75. The membrane was blocked with $10 \%$ milk powder in $20 \mathrm{mM}$ Tris- $\mathrm{HCl}$, $150 \mathrm{mM} \mathrm{NaCl}, 0.05 \%$ Tween-20 (TBST) for $1 \mathrm{~h}$ at room temperature (RT). After washing, the membrane was incubated 
with anti-human-FGF antibody diluted in 5\% milk powder in TBST for $1 \mathrm{~h}$ at RT. The membrane was washed three times, and the second anti-mouse-anti-IgG antibody in a 1:75 dilution in 5\% milk powder in TBST was added. After the $1 \mathrm{~h}$ incubation the membrane was washed and developed with a carbazol solution (basic carbazol solution, 0.1 M sodium acetate, $30 \% \mathrm{H}_{2} \mathrm{O}_{2}$ ).

Alternatively the gels underwent silver-staining instead of Western blotting. A commercial kit from Pharmacia was used for the silver-staining and a silver marker kit from BioRad Lab was used according to the protocol.

ELISA. $\alpha$-ECGF concentrations were determined by ELISA by plates coated with $200 \mu \mathrm{l} / \mathrm{ml}$ of rabbit-anti-aFGF. The plates were incubated overnight at $4^{\circ} \mathrm{C}$. The incubation was followed by a wash, carried out 3 times, using $2 \mathrm{M}$ Tris- $\mathrm{HCl}$, $10 \%$ Tween-20, 2\% merthiolat, $\mathrm{pH}$ 8.0. The wells were blocked with $50 \mu \mathrm{l} /$ well blocking buffer $(10.5 \mathrm{~g}$ boric acid, $7 \mathrm{~g}$ $\mathrm{NaCl}, 500 \mu 1$ Tween-20, $0.372 \mathrm{~g}$ EDTA, $2.5 \mathrm{~g}$ gelatine, 2\% $\mathrm{NaN}_{3} / \mathrm{l}$ distilled water) for $1 \mathrm{~h}$ at $37^{\circ} \mathrm{C}$. After the washing $50 \mu \mathrm{l} /$ well of the positive controls (commercial aFGF) or $50 \mu 1$ of the eluate was added and incubated for $1 \mathrm{~h}$ at $37^{\circ} \mathrm{C}$. After washing $50 \mu \mathrm{l} /$ well of the second peroxidase-linked antibody (goat-anti-rabbit-anti-IgG, Conco) was added. After $1 \mathrm{~h}$ of incubation and washing, $50 \mu 1 /$ well substrate (OPD, substrate buffer, $30 \% 4.5 \mathrm{mM} \mathrm{H}_{2} \mathrm{O}_{2}$ ) was added and the plates were incubated for $20 \mathrm{~min}$ in the dark. Finally the reaction was stopped with $50 \mu \mathrm{l} /$ well $4.5 \mathrm{mM} \mathrm{H}_{2} \mathrm{SO}_{4}$ and the $\alpha$-ECGF concentrations were measured in the ELISA-reader at $\mathrm{A}_{492 \mathrm{~nm}}$.

Chorioallantoic membrane assay. The CAM assay was used to show the angiogenic potency of the purified $\alpha$-ECGF. By using the established method of Auerbach, et al (32) and Wilting, et al (33) the effect of the growth factors was observed with a light microscope. Fertilized hen eggs were incubated for 13 days at $37.5^{\circ} \mathrm{C}, 66.6 \%$ humidity. The eggs were prepared by cutting a window in the oval side of the shell after three days of incubation. The ECGF and heatdenatured ECGF $\left(60^{\circ} \mathrm{C}\right.$ for $\left.30 \mathrm{~min}\right)$ were dissolved in PBS buffer and applied on thermanox coverslips with a diameter of $5 \mathrm{~mm}$. After air drying, the slips were turned upside-down on chorioallantoic membranes. The eggs were incubated for an additional three days and the membranes were removed from the eggs and fixed in fixation buffer (3\% glutaraldehyde, $3 \%$ formaldehyde in $0.12 \mathrm{M}$ sodium cacodylate buffer). The membranes were examined under a light microscope, magnification $\times 10$. The photographed angiogenesis was evaluated under blind study conditions using a score between 0 and 6 .

${ }^{3} H$-thymidin-proliferation assay. Following an established technique (34) $200 \mu 1 /$ well of BHK-21 (baby hamster kidney) cells were seeded into 96 -well plates at $1.5 \times 10^{4} / \mathrm{ml}$ in growth medium (MEM with Glutamax-I, $10 \%$ fetal calf serum (FCS): 100 IU penicillin, $0.075 \%$ sodium bicarbonate, $1 \mathrm{mM}$ sodium pyruvate, and $10 \mathrm{mM}$ HEPES). After $24 \mathrm{~h}$ the growth medium was replaced by $200 \mu 1$ starving medium (without FCS) and incubated for another $24 \mathrm{~h}$. The starving medium was replaced by stimulating medium (1\% FCS), and $20 \mu \mathrm{l} /$ well $\alpha$-ECGF was added. After $24 \mathrm{~h}$ of incubation the cells were marked by adding $1 \mathrm{Ci} /$ well of methyl- ${ }^{3} \mathrm{H}$-thymidine and again incubated for $4 \mathrm{~h}$. The medium was then removed by filtration with a FilterMate ${ }^{\mathrm{TM}}$ cell harvester. Each well was incubated with $100 \mu 10.05 \%$ trypsine/0.02\% EDTA at $\mathrm{RT}$, and after $10 \mathrm{~min}$ the cells were harvested with the FilterMate cell harvester on a UniFilter ${ }^{\mathrm{TM}}$ plate. The filter was washed, dried, and $30 \mu \mathrm{l} /$ well scintillation fluid MICROSCINT ${ }^{\mathrm{TM}} 20$ from Packard was added and counted in a TopCount NXT ${ }^{\mathrm{TM}}$.

Pyrogenicity testing of $\alpha$-ECGF. The amount $(1.1 \mathrm{mg})$ of $1 \mathrm{ml}$ ECGF was injected intravenously into the ear veins of two New Zealand white rabbits. One additional rabbit was injected with sterile pyrogen-free PBS. Rectal temperatures were taken every $30 \mathrm{~min}$ for $3 \mathrm{~h}$.

\section{Results}

Transformation. Earlier experiments have shown that only freshly transformed bacteria produced an optimal ECGF expression, therefore cultures were started immediately after transformation. However, as shown in Fig. 1 each of the 10 different clones collected after transformation produced significant amounts of ECGF. The $\alpha$-ECGF expression and the amount of contaminating $E$. coli impurities varied to a large extent.

Clone Nr. 5 and 6 were selected for large-scale production. From 51 of IPTG-induced E. coli suspension, $15 \mathrm{~g}$ of bacteria (wet weight) was obtained (Fig. 1).

Ionic exchange chromatography. By using a linear gradient of the sodium solution (from $0.15 \mathrm{M} \mathrm{NaCl}$ to $0.5 \mathrm{M} \mathrm{NaCl}$ ) the peaks during cation exchange column chromatography were collected in an elution period. A first small peak was collected 9 min after starting the elution of the proteins. The $\alpha$-ECGF fraction was eluted in a peak, which was detected 15 min after the start of the elution. The extinctions of the various samples, being collected during ionic exchange, were measured with a photometer $\left(\mathrm{A}_{280 \mathrm{~nm}}\right)$. A photometric-defined protein concentration of $0.2 \mathrm{mg} / \mathrm{ml}$ elution was reached (Fig. 2).

Heparin-sepharose affinity chromatography. The protein peak of $\alpha$-ECGF realized in exchange chromatography was achieved after desalting on a heparin-sepharose affinity chromatography column which further reduced the contamination with the endotoxin. Increasing salt concentrations $(0.15 \mathrm{M}, 0.6 \mathrm{M}$, and $1 \mathrm{M})$ were used to discern the optimal desalting concentration through comparison of protein peaks. The largest protein peak correlating to $200 \mathrm{mg}$ of $\alpha$-ECGF, was eluted using a $2 \mathrm{M}$ $\mathrm{NaCl}$ concentration, $38 \mathrm{~min}$ after the start of elution (Figs. 3 and 4).

Proof of angiogenic and mitogenic potency. Three days after ECGF-application the membranes of the chicken embryos were examined under light microscopy. The membranes supplied with the growth factor showed a great variation in the vascular structure compared to the heat-denatured samples. $\alpha$-ECGF induced an impressive growth of angiogenic structures which emanated radially from the membrane. A large number of neo-angiogenic vessels spread out of the 


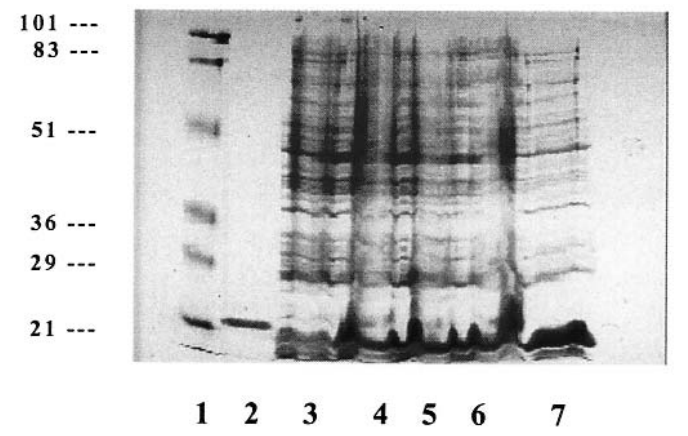

Figure 1. Samples of transformed BL21(DE)pLys-E. coli cells before and after IPTG-boostering. The proteins were separated on a $15 \%$ SDSpolyacrylamide gel and stained with Coomassie Blue. The lanes show a distinct increase in $\alpha$-ECGF ( $\mathrm{MG}=17000 \mathrm{kDa}$ ) concentration after boostering. The human growth factor aFGF (MG=18000 kDa) served as a marker protein. Lane 1, molecular weight marker; lane 2, aFGF (18000 kDa); lane 3, E. coli-lysate before IPTG induction; lanes 4-6, lysate 1, 2 and $3 \mathrm{~h}$ after boostering; lane 7, product of high-pressure homogenization. The molecular weights of the size standard proteins are indicated.

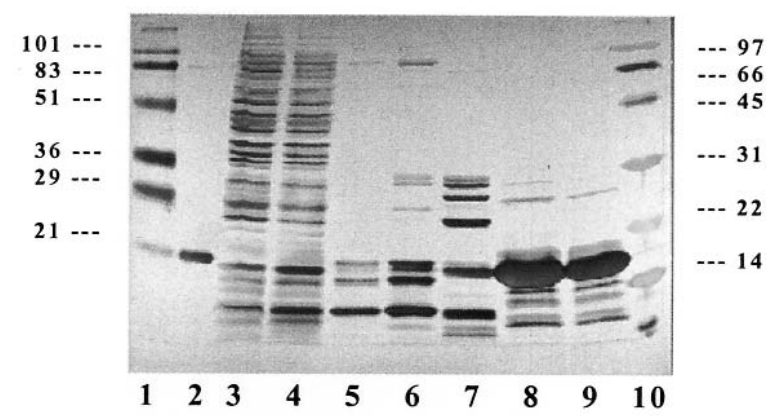

Figure 2. Samples on a silver-stained gel indicating the $\alpha$-ECGF $(\mathrm{MG}=17000 \mathrm{kDa})$ concentration after ammonium sulphate precipitation and ionic exchange chromatography during the purification process. This shows an infinitely small loss of $\alpha$-ECGF (17000 $\mathrm{kDa}$ ) while pumping the lysate on the C-50 cation exchange column. The washing process with a $0.15 \mathrm{M} \mathrm{NaCl}$ salt solution caused significant elution of growth factor. A first pre-peak sample was collected during a linear salt gradient elution and was found to contain a distinct amount of $\alpha$-ECGF quantity. Chromatography with a linear gradient of $0.15 \mathrm{M}$ and $0.5 \mathrm{M} \mathrm{NaCl}$ concentrated the growth factor sample and withheld the majority of contaminating $E$. coli proteins from the sample. Lane 1, molecular weight marker; lane 2, aFGF (18000 kDa); lane 3, lysate before IPTG induction; lane 4, lysate after ammonium sulphate precipitation; lane 5 , loss of proteins during packing of the column; lane 6 , eluate during washing process with $0.15 \mathrm{M} \mathrm{NaCl}$; lane 7, pre-peak during elution; lanes 8 and 9, main peak in gradient elution $(\alpha-\mathrm{ECGF}=17000 \mathrm{kDa})$; and lane 10, silver marker proteins. The molecular weights of the marker proteins are indicated.

original host vessels. These changes were completely absent in the control group embryos, in which a normal developed reticular vascular web was discerned.

The ${ }^{3} \mathrm{H}$-thymidine assay showed a dose-dependent 7 -fold increase of DNA synthesis in the ECGF-stimulated cultures, whereas the assays without growth factor showed cessation of cellular proliferation. After heat denaturation of ECGF $\left(60^{\circ} \mathrm{C}, 30 \mathrm{~min}\right)$ a remaining proliferative activity was observed (Figs. 5-7).

\section{Discussion}

Ischemia is characterized by inadequate blood flow and tissue oxygenation that is typically the consequence of decreased

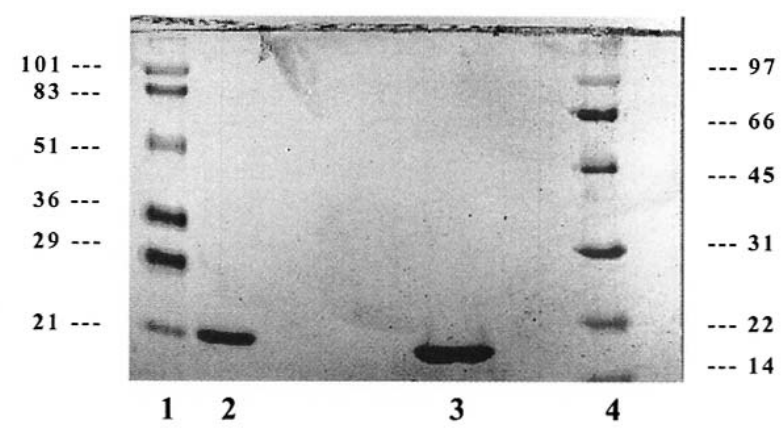

Figure 3. Silver-staining of human recombinant $\alpha$-ECGF (17000 kDa) being eluted in heparin-sepharose affinity chromatography. The gel shows a growth factor lane of high purity. Lane 1, molecular weight marker; lane 2, aFGF (18000 kDa) standard; lane 3, $\alpha$-ECGF peak of heparin-sepharose column; and lane 4, silver marker proteins.

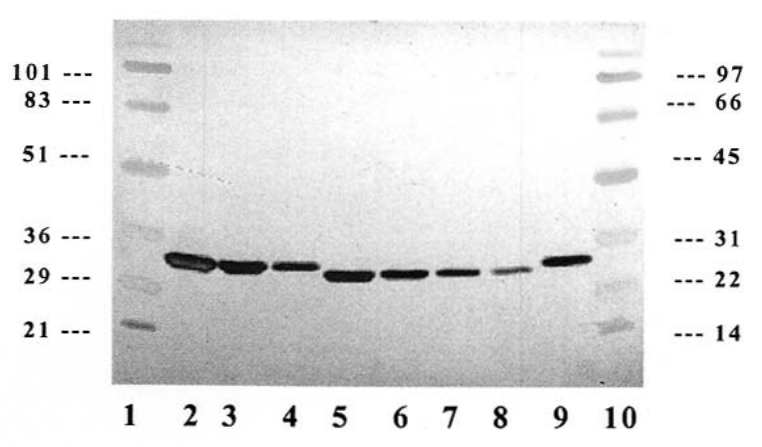

Figure 4. Silver-staining of human recombinant $\alpha$-ECGF after endotoxin absorption in polymyxine B column. Lane 1, molecular weight marker; lanes 2-4 in polymyxine B column. Lane 1, molecular weight marker; lanes 2-4, aFGF standard [lane 2, aFGF $(15 \mu \mathrm{g})$; lane 3, aFGF $(7 \mu \mathrm{g})$; lane 4 , aFGF $(3 \mu \mathrm{g})$ ]; lane 5-8, $\alpha$-ECGF after polymyxine B gel filtration [lane 5, $\operatorname{ECGF}(15 \mu 1)$; lane 6, ECGF (7 $\mu 1)$; lane 7, ECGF (3 $\mu 1)$; lane 8, ECGF (1.5 $\mu 1)$ ]; lane 9 , aFGF $(3 \mu \mathrm{g})$; and lane 10 , silver marker proteins.

patency of atherosclerotic vessels. The clinical strategies under present use work to increase blood flow in ischemic peripheral and cardiac muscle, and are largely dependent on vasodilation, angioplasty and surgical revascularization. Use of these successful approaches is in many ways restricted. Improvement in blood flow and muscle function could also be achieved by neovascularization, or angiogenic processes providing new collateral vessels. The therapeutic use of angiogenic growth factors has been the subject of intensive investigation over the last few years and has demonstrated promise as a potential modality to treat both acute and chronic myocardial ischemia. A number of studies have shown that by administering bFGF, collateral vessel flow and myocardial function have improved greatly in chronic myocardial and peripheral limb ischemia $(19,35)$. The administration of vascular endothelial growth factor (VEGF) (36), aFGF (FGF-1) $(20,21,37)$ and ECGF $(29,38)$ has also been reported to produce functionally significant angiogenesis.

Our aim was to produce $\alpha$-ECGF in a low-cost, fast and effective manner for clinical study towards a new treatment of coronary heart disease with growth factor application during elective bypass surgery. Fresh transformation in E. coliBL21(DE3)pLYSS-cells without storage and selection of clones achieved a higher productivity of the cultures. Highpressure homogenization (French press) proved to be a more 


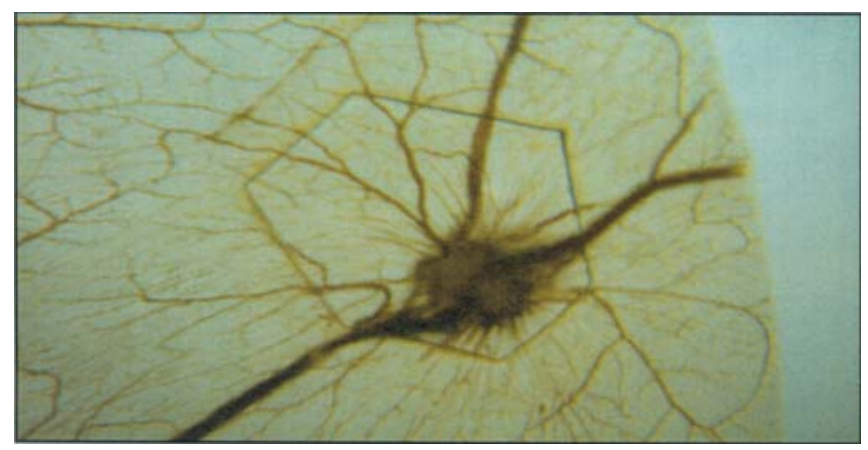

Figure 5. Chorionallantoic membrane assay with application of $6 \mu \mathrm{g} \alpha$-ECGF.

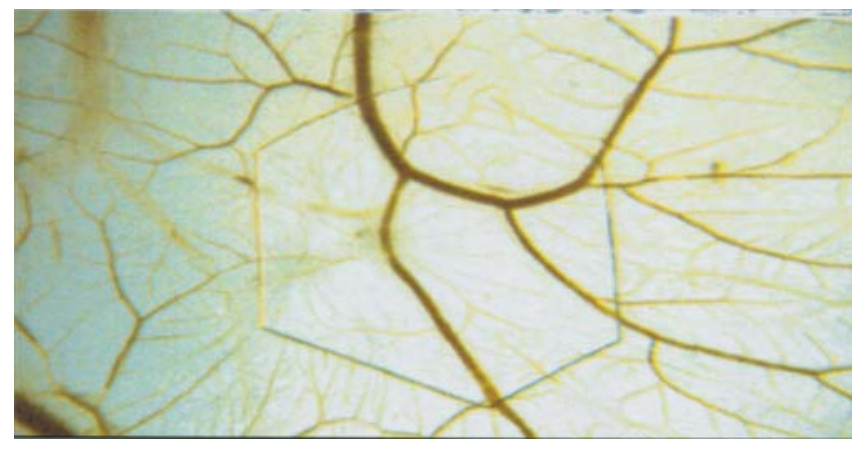

Figure 6. Chorionallantoic membrane assay with application of $6 \mu \mathrm{g}$ heatdenatured growth factor.

Stimulation of BHK-21 $\left(1,5 \times 10^{4} / \mathrm{ml}\right)$ by various concentrations of alpha-ECGF

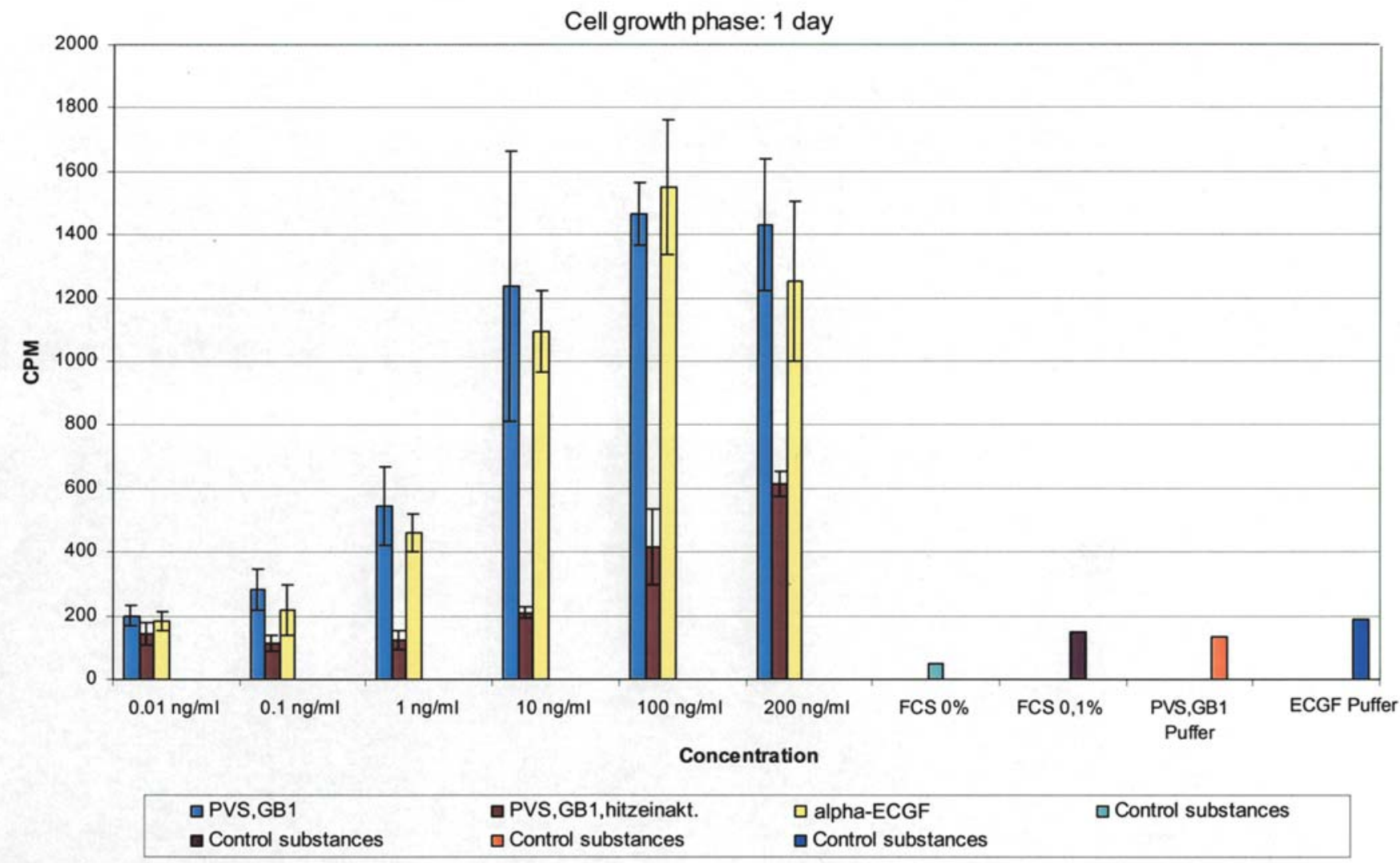

Figure 7. Rate of DNA synthesis in baby hamster kidney cells $\left(1.5 \times 10^{4} / \mathrm{ml}\right)$ during a one-day cell growth and application of various concentrations of purified human recombinant $\alpha$-ECGF.

efficient and effective method to release rh-ECGF in comparison to methods such as ultrasound sonification (39). The ammonium sulphate precipitation of the French press lysate eliminated some of the nonspecific bacterial proteins and concentrated the ECGF (34). Gel filtration in a G 25med column removed the salt fraction and reduced the viscosity of the homogenate. After gel filtration, there was no need for further reduction of the viscosity by the application of DNase (40). The cation exchange C 50 column using a linear gradient of $0.15 \mathrm{M} \mathrm{NaCl}$ and $0.5 \mathrm{M} \mathrm{NaCl}$ restricted the elution of the growth factor to one peak. In comparison this restriction failed in the purification of rh-bFGF (41). The higher molecular weight of $\alpha$-ECGF and a different isoelectric point may be explanations for this observation. The growth factor was not stabilized with the zwitterionic detergent CHAPS (43) in order to prevent side-effects in vivo. The gradient in the heparin-sepharose affinity chromatography was found to be between 0.6 and $2 \mathrm{M} \mathrm{NaCl}$. Whereas the elution of the main peak of FGF was described at a $1.4 \mathrm{M}$ $\mathrm{NaCl}$ gradient (42), the ECGF peak was collected at a $2 \mathrm{M}$ $\mathrm{NaCl}$ gradient. The polymyxine $\mathrm{B}$ column proved to be an efficient method to remove remaining endotoxin remnants, and the silver-stained gels showed no sign of a significant growth factor loss in polymyxine B column. 
As a result of the animal experiments in rabbits and the results from the limulus lysate assay we were able to exclude the pyrogenic effects of ECGF. Thus there was no need to carry out high-pressure liquid chromatography (HPLC), which represents the main aspect of the purification of heparin-binding growth factors illustrated by the aforementioned authors $(10,44)$. HPLC purification faces the problem that precipitations block the system (42). The main reason for omitting the HPLC procedure is the speculation that remnants of the TFA buffer used in HPLC induce inflammation and angiogenesis in vivo (29). Thus we sought to achieve sufficient purification without HPLC.

The production of recombinant human $\alpha$-ECGF by our new combination of biotechnological methods proved to be a complex, but efficient method to produce the large quantities of growth factor required for clinical trials. From a 5-1 culture medium (15 g bacteria) we purified, without HPLC, $200 \mathrm{mg}$ of $\alpha$-ECGF compared to the previous quantity of $60 \mathrm{mg}$ aFGF reported by other authors using the HPLC methodology (42). The biological activity of ECGF was proved in the CAM assay and this result was confirmed by the increase of DNA synthesis in BHK 21 cells. Clinical trials in patients suffering from coronary heart disease who cannot be treated with conventional bypass surgery are currently under progress.

\section{References}

1. Canty JM and Klocke FJ: Reduced regional myocradial perfusion in the presence of pharmacologic vasodilator reserve. Circulation 71: 370-377, 1985.

2. Landau C, Jacobs AK and Haudenschild C: Left ventricular hypertrophy induced by angiotensin II is accompanied by a dose dependent fibrotic response. Circulation 86 (suppl I): 754, 1992.

3. Yancy CW, Vissing S, Cuckey JC, Bellomo JF, Firth BG and Blomqvist CG: Maximal conductance versus maximal oxygen uptake in patients with congestive heart failure J Am Coll Cardiol 11 (suppl A), 73, 1988.

4. Halperin JL and Creager MA: Arterial obstructive diseases of the extremeties. In: Vascular Medicine. Loscalzo J, Creager MA and Dzau VJ (eds). Little, Brown and Company, Boston, pp835-843, 1992.

5. Klagsbrun M: Regulators of angiogenesis. Annu Rev Physiol 53: 217-239, 1991 .

6. Miyamoto M, Naruo K, Seko C, Matsumoto S, Kondo T and Kurokawa T: Molecular cloning of a novel cytokine cDNA encoding the ninth member of the fibroblast growth factor family, which has a unique secretion property. Mol Cell Biol 13: 4251-4259, 1999.

7. Thomas KA: Biochemistry and molecular biology of fibroblast growth factors. In: Neurotropic Factors. Fa JH and Loughlin SE (eds). Academic Press Inc., Orlando, pp285-312, 1992.

8. Yamasaki M, Miyake A, Tagashira S and Itoh N: Structure and expression of the rat mRNA encoding a novel member of the fibroblast growth factor family. J Biol Chem 271: 15918-15921, 1996.

9. Smallwood PM, Munoz-Sanjuan I, Tong P, Macke J, Hendry SHC, Gilbert D, Copeland NG, Jenkins NA and Nathans J: Fibroblast growth factor homologous factors: New members of the FGF family implicated in nervous system development. Proc Natl Acad Sci USA 93: 9850-9857, 1996.

10. Burgess WH, Mehlmann T, Friesel R, Johnson WV and Maciag T: Multiple forms of endothelial cell growth factors (ECGF). J Biol Chem 260: 11389-11392, 1985.

11. Gospodarowicz D: Growth factors and their action in vivo and in vitro. J Pathol 141: 201-233, 1983.

12. Folkman J and Klagsbrun M: Angiogenetic factors. Science 235: 442-447, 1987.

13. Chen JK, Hoshi H and McKeehan WL: HBGF-I and PDGF are required for the optimal expression of cell surface LDLP receptor binding activity in human adult arterial smooth muscle cells. In Vitro Cell Mol Biol 24: 199-204, 1998.
14. Senior RM, Huang SS, Griffin GL and Huang JS: Brain-derived growth factor is a chemoattractant for fibroblasts. Biochem Biophys Res Commun 141: 67-72, 1986.

15. Johnson DE and Williams LT: Structural and functional diversity in the FGFR multigene family. Adv Cancer Res 60: 1-41, 1993.

16. Guimond S and Turnbull JE: FGF receptor signalling is dictated by specific heparansulphate saccharides. Curr Biol 9: 1343-1346, 1999.

17. McKeehan WL, Wu X and Kann M: Requirement for anticoagulant heparan sulfate in the fibroblast growth factor receptor complex. J Biol Chem 274: 21511-21514, 1999.

18. Yanagisawa-Miwa A: Salvage of infarcted myocardium by angiogenic action of basic fibroblast growth factor. Science 257: 1401-1403, 1992.

19. Lopez J, DiSalvo J, Douglas P, Sellke F and Simons M: Perivascular delivery of prolonged half-life aFGF via EVAc results in angiographic collateral development, improvement in coronary flow and function in chronic myocardial ischemia. $\mathrm{J}$ Am Coll Cardiol 27: 30A, 1996.

20. Schumacher B, von Specht BU, Haberstroh J and Pecher P: The stimulation of neoangiogenesis in the ischemic heart by the human growth factor FGF. J Cardiovasc Surg 39: 445-453, 1998.

21. Schumacher B, Pecher P, von Specht BU and Stegmann Th: Induction of neoangiogenesis in ischemic myocardium by human growth factors: First clinical results of a new treatment of coronary heart disease. Circulation 97: 645-650, 1998.

22. Laham RJ, Sellke FW, Edelman ER, Pearlman JD, Ware JA, Brown DL, Gold JP and Simons M: Local perivascular delivery of basic fibroblast growth factor in patients undergoing coronary bypass surgery: Results of a phase I randomized, double-blind, placebo-controlled trial. Circulation 100: 1865-1871, 1999.

23. Gospodarowicz D, Bialecki $\mathrm{H}$ and Greenberg G: Purification of the FGF activity from bovine brain. J Biol Chem 253: 3736-3743, 1978.

24. Schreiber AB, Kenny J, Kowalski WJ, et al: Interaction of ECGF with heparin: characterization by receptor and antibody recognition. Proc Natl Acad Sci USA 82: 6138-6142, 1985.

25. Schreiber AB, Kennedy J, Kowalsky WJ, et al: A unique family of endothelial cell polypeptide mitogens: the antigenic and receptor cross-reactivity of bovine endothelial cell growth factor, brain-derived acidic fibroblast growth factor, and eyederived growth factor-II. J Cell Biol 101: 1623-1626, 1985.

26. Thornton SC, Mueller SN and Levine EM: Human endothelial cells: use of heparin in cloning and long-term serial cultivation. Science 222: 623-625, 1984.

27. Maciag T, Hoover GA and Weinstein R: High and low molecular weight forms of ECGF. J Biol Chem 257: 5333-5336, 1982.

28. Maciag T, Mehlman T, Friesel R and Schreiber AB: Heparin binds endothelial cell growth factor, the principal endothelial cell mitogen in bovine brain. Science 225: 932-934, 1984.

29. Schlaudraff K, Schumacher B, von Specht BU, Seitelberger R, Schlosser V and Fasol R: Growth of new coronary vascular structures by angiogenetic growth factors. Eur J Cardiothorac Surg 7: 637-644, 1993

30. Forough R, Engleka K, Thompson JA, Jackson A, Imamura T and Maciag T: Differential expression in Escherichia coli of the alpha and beta forms of heparin-binding acidic fibroblast growth factor 1: potential role of RNA secondary structure. Biochem Biophys Acta 1090: 293-298, 1991.

31. Schagger $H$ and von Jagow G: Tricine-sodium dodecyl-sulfate ployacrylamide gel electrophoresis for the separation of proteins in the range from 1 to $100 \mathrm{kDa}$. Anal Biochem 166: 368-379, 1987.

32. Auerbach R, Kabail L, Knighton D and Folkman J: A simple procedure for the long-term cultivation of chicken embryo. Dev Biol 41: 391-394, 1974

33. Wilting J, Christ B and Bokeloh M: A modified chorioallantoic membrane (CAM) assay for qualitative and quantitative study of growth factors. Anat Embryol 183: 259-271, 1991

34. Gospodarowicz D and Cheng J: Heparin protects basic and acidic FGF from inactivation. J Cell Physiol 128: 475-484, 1986.

35. Lazarous DF, Scheinowitz M, Shou M, et al: Effects of chronic systemic administration of basic fibroblast growth factor on collateral development in the canine heart. Circulation 91: 145$153,1995$.

36. Isner JM, Pieczek A, Schainfeld R, et al: Clinical evidence of angiogenesis after arterial gene transfer of pHVEGF165 in patient with ischaemic limb. Lancet 248: 370-374, 1996. 
37. Lopez J, Edelman ER, Stamler A, et al: Angiogenic potential of perivasculary delivered aFGF in a porcine model of chronic myocardial ischemia. Am J Physiol 274: H930-H936, 1998.

38. Schlaudraff K, Schumacher B, Seitelberger R, von Specht BU, Schlosser V and Fasol R: An experimental study of in situ and in vivo growth of new arteries by angiogenic growth factor HBGF-I. Thorac Cardiovasc Surg 40: 136-142, 1992.

39. Schlaudraff KU, von Specht BU, Kolvenbach H, Stegmann Th and Schumacher B: Induction of new blood vessels in patients with the first clinical application of the human HBGF-I. Langenbecks Arch Chir 379: 167-172, 1994.

40. Garke G, Deckwer WD and Anspach FB: Preparative two-step purification of recombinant human basic fibroblast growth factor from high-cell-density cultivation of Escherichia coli. J Chromatogr B Biomed Sci Appl 737: 25-38, 2000.

41. Garke G, Radtschenko I and Anspach FB: Continuous-bed chromatography for the analysis and purification of recombinant human basic fibroblast growth factor. J Chromatogr A 857: 137-144, 1999.
42. Ke LD, Karaganis AG and Shain SA: A rapid, two-step method for high-yield purification of recombinant rat acidic and basic fibroblast growth factors. Protein Expr Purif 3: 497-507, 1992

43. Matuo Y, Nishi N, Muguruma Y, Yoshitake Y, Masuda Y, Nishikawa K and Wada F: Stabilization of fibroblast growth factors by non-cytotoxic zwitterionic detergent, 3-[(3cholamidopropyl)dimethylammonio]-1-propane sulfonate (CHAPS). In Vitro Cell Dev Biol 24: 477-480, 1988.

44. Lametsch R, Rasmussen JT, Johnsen LB, Purup S, Sejrsen K, Petersen TE and Heegaard CW: Structural characterization of the fibroblast growth factor-binding protein purified from bovine prepartum mammary gland secretion. J Biol Chem 275: 19469-1947, 2000. 